picious to the Board of Health of the state indicated by his ticket. The health officer of that state should keep him and his family under supervision for seven years.

2. It should be a penal oifense for a steamship company to carry an emigrant from a leprous country without the health permit of the American Consul.

3. Should a leper precent himself for emigration. to the United States Consulate, he should be turned back to the authorities of his own country.

4. A leper who has escaped supervision or detection at the port of embarkation, and at the port of entry in America, should be reported to his own country through his Consul residing in the port of entry in America, who shall send him back at the expense of his own country.

5. Norwegians and Swedes (and Russians) of leprous families, should choose for settlement, states like Minnesota, Wisconsin, North and South Dakota, and Western Kansas, whose climate is antagonistic to the life and multiplication of the bacilli. Under no circumstances should they settle near the Atlantic coast line, near the northern lakes, or in the cotton belt, whose climate is quite the opposite of the other.

6. Any suspicious emigrant should be for seven years, under what the French call surveillance de la haute police, therefore should not be permitted to go from one state to another without the latter being duly informed of the fact by the former.

Alber' S. Asmiread, M.D.

\section{Intubation and Antitoxin in Diphtheritic Laryngitis.} Chicago, Oct. 10, 1899.

To the Editor:-Intubation of the larynx in diphtheritic stenosis before antitoxin came into such general use, was much more common than now. Indeed, antitoxin seems to have very largely done away with the necessity for intubation.

It is my firm eonviction that: 1 , when antitoxin is used early, the larynx will not become involved nearly as often as without it; 2, when the disease commences primarily in the larynx, it is sometimes arrested, requiring no surgical interference; and 3 , when intubation is necessary, recoveries are more frequent than before antitoxin days.

My experience in the surgical treatment of diphtheritic laryngitis is linited to 234 cases, the tube having been inserted in the last case twenty-four hours ago, and the patient is still wearing the tube, having a good prospect of recovery. All occurred in private practice. Tracheotomy was done in 30 of these, with a recovery of 24 per cent.; 150 were intubated with a recovery of 40 per cent., and 53 were treated with antitoxin and intubation and show a recovery of 60 per cent. These results speak more forcibly than words, and are about on a par with those obtained by other operators. Some have shown a greater, some a less percentage of recoveries, the difference, depending largely on early or late operating, the type of the disease, mild or severe, malignant or non-malignant. There can be no doubt that the surgical treatment of this disease has steadily advanced, from tracheotomy to intubation, from intubation to intubation with antitoxin. The exact increase in the percentage of recoveries may never be known; we care little or nothing for this. The broad fact remains the same, that a vastly greater number of children recover, with the aid of antitoxin and intubation, than with intubation alone.

533 W. Monroe St. Alrert B. Stroxg, M. D.

\section{Primary Testicular Mumps.}

So. Royaltox, Vt., Oct. 1i, 1899.

To the Editor:-I was mueh interested in Dr. Landon $\mathbf{B}$. Edwards' article in the Journat, October 14, on the above subject. One similar case occurred in my practice several years ago, in a carpenter, a married man, of excellent habits. I was treating several cases of mumps in his family at the time. He was at work cn a building across the street from my office and came in saying that his testicles were paining him, and on examination I found they were both swollen and tender. The next day there was an increase of swelling, pain, tenderness, and a rise in temperature. This continued for two or three days more, when a very decided parotiditis uccurred. The testicles did not become atrophied and I have since attended his wife in a confinement. For several years I have closely watched literature and society reports and have not received any light from either source on the condition under consideration. Yours, very truly,

D. I. Burnett, M.D.

\section{Early Conception Following Labor. LAPoRTE, IND., Oct. 10, 1899.}

To the Editor:-Gould and Pyle, in their work "Anomalies and Curiosities of Medicine," mention several cases of early conception after a preceding pregnancy varying from forty hours to twenty-eight days. I desire to place on record another case: Mrs. B. was delivered on Dec. 5, 1898, of a girl. On September 27, ]899, she was again delivered of a boy at full term. She must have become pregnant on or about Dec. $2 \pi$, 1898, just twenty-two days after the delivery of her first child.

$$
\text { Yours truly, }
$$

$$
\text { E. L. ANnis, M.D. }
$$

\section{Washington, D. C. \\ (From Our Rogular Correspondent.) HEALTH OF THE DISTRICT.}

The report of the health ofticer for the week ended October 14 shows the total number of deaths to have been 139,74 white and 65 colored. At the close of the week there were 69 eases of diphtheria and 75 of scarlet fever under treatment. There were 74 birtins and 32 marriages during the week.

CENTRAI, DISPLNSARY AND EMERGENCY HOSPITAL.

At the meeting of the Board of Trustees of the Hospital, recently held, the report of the attending staff for the past month was presented and showed the total number of cases treated as follows: emergency, 638; dispensary, 2588; ward, 55 ; deaths, 8 ; prescriptions, 3210 ; ambulance calls, 82 .

EPISCOPAL EYE AND EAR IIOSPITAL.

At the recent meeting of the trustees of this institution, the attending stafi reported that during the past nine months, 1111 patients have been treated, 528 white and 537 colored; 112 patients have been received in the wards and 150 operations performed.

\section{Canada. \\ (From Our Reqular Corresponicnt.) Tonorro, Oet. $14,1899$. \\ LUXACY AXD CRIME IN QUEBEC.}

In a paper on "Judicial Errors in Lunacy," prepared by Dr. Geo. Villeneuve, associate professor of mental diseases and medical jurisprudence, Javal University, and medical superíntendent, St. Jean de Dieu Asylum, Longue Pointe, Que., and Dr. E. P. Chagnon, assistant physician, same asylum, and read at the fifty-fifth annual meeting of the American MedicoPsychological Association, held in New York in May last, the writers limit the scope of their investigations to cases which have come under the jurisdiction of the criminal courts of the Province of Quebec and refer only to those lunatics who have been convicted and sentenced. These lunatics who have suffered punishment at the hands of the criminal courts of the province are by them divided into two classes. Class A embraces those unfortunate ones who have been submitted to. medical examinations and found insane, but who have been convicted and sentenced by the courts in spite of the opinion of the medical experts who advised of their irresponsibility. These proceedings, the writers denominate "judicial errors" intentional. In Class $\mathrm{B}$ are included all those insane persons "whose mental derangement has not been recognized" at the 